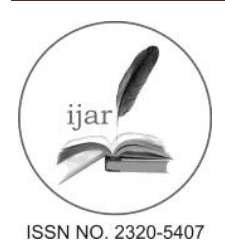

Journal homepage: http://www.journalijar.com
Journal DOI: 10.21474/IJAR01

INTERNATIONAL JOURNAL

RESEARCH ARTICLE

\title{
ECO-FRIENDLY MANAGEMENT OF SCLEROTIUM ROLFSII CAUSING ROOT ROT DISEASE IN CHILLI.
}

\begin{abstract}
Uzma Quadri ${ }^{1}$, Sumia Fatima. ${ }^{2}$
1. Research Student, Department of Botany, Dr. Rafiq Zakaria Women College, Aurangabad, Maharashtra, India.

2. Associate Professor and Head of Department, Department of Botany, Dr. Rafiq Zakaria Women College, Aurangabad, Maharashtra, India.
\end{abstract}

\section{Manuscript Info}

Manuscript History:

Received: 16 March 2016

Final Accepted: 19 April 2016

Published Online: May 2016

Key words:

Annona squamosa Linn, Biological control, Brassica campestris Linn. (Sarson), Medicinal plants, Sclerotium rolfsii and Ocimum sanctum Linn.

*Corresponding Author

Uzma Quadri.

\begin{abstract}
Synthetically chemical fungicides have long been used to reduce the incidence of plant diseases. However they are costly, can have negative effects on the environment and may induce pathogens resistance. The application of chemical compounds is consider as the most in expensive and common method in plant disease control. Therefore efficacy of leaves extracts of Annona squamosa Linn, Brassica campestris Linn. (Sarson) and Ocimum sanctum Linn against Sclerotium rolfsii was studied. The in vitro antifungal activity of these Annona squamosa Linn, Brassica campestris Linn. (Sarson) and Ocimum sanctum Linn leaves extract was investigated. The medicinal plant leaves extract of $10 \%, 25 \%, 50 \%, 75 \%$ and $100 \%$ (without treatment serve as control) in aqueous medium were select for made. Inhibited values recorded. In the case of Brassica campestris Linn (Sarson) 8.534, 9.302, 11.24 and 10.86 percentage of inhibition recorded at $10,25,50$ and 75 percent concentration after 72 hours incubation periods. The Annona squamosa Linn leaves gave $21.33 \mathrm{~mm}$ mycelial growth at 25 percent concentration of with 3.045 percent of inhibition $77.33 \mathrm{~mm}$ mycelial growth at 50 percent aqueous concentration gave 3.337 least percentage of inhibition. The Ocimum spp. revealed 32.00 and 30.68 percentage of inhibition with $17 \mathrm{~mm}$ and $17.33 \mathrm{~mm}$ mycelial growth at $50 \& 75$ percentage concentration of Ocimum spp. aqueous leaves extract after 24 hours. The maximum inhibition was $74.33 \mathrm{~mm}$ and $73.33 \mathrm{~mm}$ at 25 percent and 50 percent of Ocimum spp. aqueous leaves extract after 72 hours of incubation period. All used concentration of three medicinal plant leaves extracts effectively suppress the radial mycelial growth of Sclerotium rolfsii ranging from $2.197 \%$ of inhibition in Ocimum spp. at $25 \%$ of concentration after 72 hours, to $32.00 \%$ of inhibition in same Ocimum spp. leaves extract at $50 \%$ concentration leaves aqueous leaves extract after 24 hours incubation periods. However $0 \%$ gave by Brassica compestris leaves extract of $10 \& 25$ concentration after 24 hours of incubation period. The present study was conducted with an aim of determining antifungal activity of medicinal plant leaves extract of Annona squamosa, Brassica campestris Linn. (Sarson) and Ocimum sanctum Linn.
\end{abstract}

\section{Introduction:-}

Plant extract are eco-friendly display structural diversity and complexity and frequently contain secondary metabolites. These chemicals bear a variety of properties like antifungal and others (Parajuli et.al., 1998). Herbal medicinal are used as therapeutic agents (Kondratyak and Pezzuto, 2004; Mothana and Lindquist, 2005; Zaidi and 
Crow Jr, 2005), many of these plants were screened for various biological and pharmacological activities including antifungal, antibacterial, insecticidal activities. ;( Al-Mughrabi, 2003; Ismail et al. (2003), (2007); Hoffman et.al. 2004).

Synthetic fungicides are currently used as primarily means use for to control plant diseases, however, the attractive control methods are needed because of negative public perceptions about the use of synthetic chemicals resistance to fungicides among fungal pathogens and high development cost of new chemicals. There is therefore the need to search for the use of cheaper environmentally available alternatives such as plant extracts for the control of Sclerotium rolfsii. The plants as medicine are widespread throughout the world.

Management of the plant diseases incited by soil borne pathogens is not achievable chemically; due to the wide spread host range, abundant growth of pathogen and its capacity of producing excessive sclerotia that may persist in soil for several years. Organic soil amendment and eco-friendly bio fungicides are a beneficial approach for controlling chilli disease causing root rot by soil born pathogen Sclerotium rolfsii.

Large number of plant have been reported to possess fungi toxic could be exploited commercially with practicality no residual or toxic effect on ecosystem (Kumar et al, 2008). Protective, curative and antagonistic activity of different plants against variety of diseases has been reported by several workers (Kandasamy et al., 1974; Hala and Mathers, 1977; Rahber-Bhatti, 1986; Kalo and Tanigueshi 1987). The leaves extract of Annona squamosa was record inhibition on radial growth of Sclerotium rolfsii Sacc. causing stem rot of Groundnut by Darvin G. (2013). Sehhajpal, A \& et al., (2009) was noticed that Brassica compestris showed least mycelial growth and inhibition of pathogen Rhizoctonia solani. Therefore it is necessary to search for control measures that are cheap, ecological sound the environmentally safe to eliminate or reduce the incidence of economic importance pathogens and to increases both seed germination and yield of plant crops.

Our goal was to test the application of Annona squamosa Linn, Brassica compestris Linn and Ocimum sanctum Linn medicinal plant leaves extracts, for protecting this plant crop form S.rolfsii. The present study was ascertained to investigate the inhibitory effect leaves extracts of Annona squamosa Linn, Brassica compestris Linn and Ocimum sanctum Linn various plants species on the Sclerotium rolfsii under in-vitro conditions.

\section{Material and Methods:-}

\section{Isolation of Sclerotium rolfsii:-}

Infected root rot disease of chilli plant caused by Sclerotium rolfsii was collected from the field of Aurangabad District. The cut the infected portion into small pieces of about $3-5 \mathrm{~mm}$ thick and sterilized with $0.1 \%\left(\mathrm{HgCl}_{2}\right)$ mercuric chloride solution for few seconds and rinsed thrice in sterilized distilled water, and then placed on filter paper at room temperature. The tissue sections were then placed on potato dextrose agar and incubated at room temperature for seven days. Ultimately the pure culture of the pathogen was isolated subsequently maintained on the potato dextrose agar medium. Potato dextrose agar medium was prepared and after room temperature in poured petriplates of the medium, mycelial disk 4mm diameter were cut from 4-5 day-old actively growing culture of the Slcerotium rolfsii and each was placed in the center of petriplates containing PDA. The effect of plant extracts on inhibition the Sclerotium rolfsii was studied using poisoning food technique, (Dhingra and Sinclair, 1985).

\section{Plant species with families selected:-}

The effect of plant leaves extracts on inhibition the Sclerotium rolfsii was studied. Plant species with species and families were selected for in-vitro evaluation used for this study was presented in the Table 1 below.

Table 1

\begin{tabular}{|c|c|c|}
\hline Sr.No. & Botanical name of medicinal Plants & Families \\
\hline 1 & Annona squamosa Linn. & Annonaceae \\
\hline 2 & Brassica compestris Linn. & Brassicaceae / Cruciferaceae \\
\hline 3 & Ocimum sanctum Linn. & Lamiaceae / Labiaceae \\
\hline
\end{tabular}

\section{Preparations' of plant extract:-}

Fresh leaves of Annona squamosa Linn, Brassica compestris Linn and Ocimum sanctum Linn. were used medicinal plants leaves extract perpetration. These leaves were collected from Phulambari road side's field in Aurangabad District during January, February 2015. These plants leaves, were rinsed in sterile distilled water in two to three 
times and dried in shied at room temperature, after which they were milled motor and pestle and electric blender to make powder. The powders were packed in to bottles and in air tight plastic pouches.

\section{Preparation plant extract medium for different concentration:-}

The plant leaves extract Annona squamosa Linn, Brassica compestris Linn and Ocimum sanctum Linn. of were made with at the rate of one $\mathrm{ml} /$ one gm or one $\mathrm{gm} /$ one $\mathrm{ml}$ of sterilized distilled water, autoclaved cooled and then strained through muslin cloth. This formed a standard plant extract were made in aqueous medium of $10 \%, 25 \%$, $50 \%, 75 \%$ and control (a without plant leaves extracts) concentrations.

\section{Studies effect of plant extracts of different concentrations:-}

The effect of plant leaves extracts of Annona squamosa Linn, Brassica compestris Linn and Ocimum sanctum Linn on the growth of Sclerotium rolfsii were studied by using poisoned food technique. From standard stock solutions of plants leaves $10,25,50,75$ percentage concentrations was prepared separately by adding the required quantity of plants extract to the molten potato dextrose agar medium. One set is made without plant extract and kept as control. All theses poured in to sterilized Petri plates. A mycelial disk of $4 \mathrm{~mm}$ cut from the periphery to 3-4 days old colony of Sclerotium rolfsii grown on potato dextrose agar medium were centrally placed in each of the Petri plates containing the potato dextrose agar medium having different three leaves extracts of Annona squamosa Linn, Brassica compestris Linn and Ocimum sanctum at different 10\%, 25\%, 50\%, 75\% concentrations and control under aseptic conditions. The Petri plates contains the PDA medium inoculated with the pathogen alone served as control. All these petriplates were incubated at room temperature. There are three replication were maintained for each treatment. The diameter of the colony was measured in two directions and average was recorded. The inhibition the Sclerotium rolfsii was calculated by using the formula given below.

$$
\text { Percentage of inhibition }=\frac{[\text { Diameter of colony }]-[\text { Diameter of colony in treatment }]}{\text { Diameter of colony control }} \times 100
$$

\section{Result and Discussion:-}

Antifungal activity of Annona squamosa Linn, Brassica compestris Linn and Ocimum sanctum Linn medicinal plants leaves were assayed by food poisoning method. From table 1, 2 and 3, figure 1 and graph 1-6 revealed that the extract of above three medicinal plants showed reduction in growth of Sclerotium rolfsii. Among all three plants extract in aqueous medium Ocimum sanctum Linn exhibit maximum antifungal activity \& maximum inhibitions percentage $20.8 \%$ with $67.3 \mathrm{~mm}$ growth at 75 percentage concentration, followed by Annona squamosa Linn which at $75 \%$ concentration gave $69 \mathrm{~mm}$ growth, with 18.8 percent of inhibition. Jalal and Ghaffar (1992) studied antifungal characteristics' of Ocimum sanctum Linn. and found that it is leaf extract completely inhibited the Sclerotium rolfsii and other fungi. The Brassica campestris Linn. aqueous leaves extract resulted maximum growth $77.6 \mathrm{~mm}$ and proved as least inhibitor that shows $10.23 \%$ percent of inhibition at 10 percent concentration. The results of fungicidal effects of aqueous extract of all tested three plants showed moderate to minimum activity against Sclerotium rolfsii better than no activity of medicinal leaves as fungicides.

\section{Discussion:-}

The fungicidal efficacy of three plant extracts were tested against Sclerotium rolfsii the minimum growth and maximum inhibitory activity found in Ocimum sanctum Linn. Three plants extracts showed fungi toxic potentiality out of which O.sanctum belongs $11.76 \%$ to $20 \%$ were maximum against the test pathogen, it indicated it broad range of activity as compared to other two Annona squamosa Linn, Brassica compestris Linn. However, Brassica compestris Linn showed least exhibition of test pathogen. These antifungal effects of different concentration of Brassica compestris Linn plant leaves extracts on the pathogen Rhizoctonia solani was found in Anil Sehajpal, Arora and Parminder Kaur ( 2009 ). O.santum aqueous extract gave reduction in the work of Awauah (1989) against Rhizopus species. Okigbo and Ogbonnanya (2006) reported that $O$. gratissum ethanol extracts inhibited the mycelial growth and spore germinations of many rot causing microorganisms'. 
Table 1:- Medicinal plants in aqueous medium of following concentrations impression radial growth of Sclerotium rolfsii measured in $\mathrm{mm}$ after 24 hours.

\begin{tabular}{|c|c|c|c|c|c|}
\hline $\begin{array}{l}\text { Serial. } \\
\text { No }\end{array}$ & $\begin{array}{l}\text { Medicinal } \\
\text { plants }\end{array}$ & $\begin{array}{c}\text { Concentrations } \\
(\%)\end{array}$ & $\begin{array}{l}\text { Growth } \\
\text { extracts }\end{array}$ & $\begin{array}{l}\text { S.rolfsii } \\
\text { measured } \\
24 \text { hours }\end{array}$ & $\begin{array}{l}\text { given } \\
\text { in } \mathrm{mm}\end{array}$ \\
\hline & & & $24 \mathrm{hr}$ & $48 \mathrm{hr}$ & $72 \mathrm{hr}$ \\
\hline \multirow{5}{*}{1} & \multirow{5}{*}{$\begin{array}{c}\text { Brassica } \\
\text { compestris } \\
\text { Linn. }\end{array}$} & $10 \%$ & 21 & 51 & 78.66 \\
\hline & & $25 \%$ & 20.00 & 47.33 & 78 \\
\hline & & $50 \%$ & 19.33 & 47 & 76.33 \\
\hline & & $75 \%$ & 20 & 47.33 & 76.66 \\
\hline & & Control & 21 & 56 & 86 \\
\hline \multirow{5}{*}{2} & \multirow{5}{*}{$\begin{array}{c}\text { Annona } \\
\text { squamosa } \\
\text { Linn. }\end{array}$} & $10 \%$ & 19.66 & 47.66 & 73.00 \\
\hline & & $25 \%$ & 21.33 & 47.33 & 75.66 \\
\hline & & $50 \%$ & 18.66 & 49.66 & 77.33 \\
\hline & & $75 \%$ & 18.66 & 42.66 & 70.33 \\
\hline & & Control & & & \\
\hline \multirow{5}{*}{3} & \multirow{5}{*}{$\begin{array}{l}\text { Ocimum } \\
\text { sanctum } \\
\text { Linn. }\end{array}$} & $10 \%$ & 20 & 48 & 73 \\
\hline & & $25 \%$ & 18.66 & 46.83 & 74.33 \\
\hline & & $50 \%$ & 17 & 47 & 73.33 \\
\hline & & $75 \%$ & 17.33 & 44 & 68.33 \\
\hline & & Control & & & \\
\hline
\end{tabular}

* Values are average of triplicate.

* Values measured after deducting or reducing $4 \mathrm{~mm}$ mycelium disk.

* (I) is denoted for inhibition.

* Note $1-10 \%, 25 \%, 50 \%, 75 \%$ and Control (100\%) are aqueous medium leaves extract.

Table 2:- The percentage of Inhibition (\% of I) of Sclerotium rolfsii at given plant extract concentration in aqueous medium.

\begin{tabular}{|c|c|c|c|c|c|c|c|c|}
\hline \multirow[t]{2}{*}{$\begin{array}{l}\text { Serial } \\
\text { No. }\end{array}$} & \multirow[t]{2}{*}{$\begin{array}{l}\text { Medicinal } \\
\text { plants }\end{array}$} & \multirow[t]{2}{*}{$\begin{array}{l}\text { Concentrations } \\
(\%)\end{array}$} & $\begin{array}{c}\text { Percentage } \\
\text { given }\end{array}$ & $\begin{array}{c}\text { of } \\
\text { plant }\end{array}$ & $\begin{array}{c}\text { Inhibition (I) } \\
\text { extract }\end{array}$ & $\begin{array}{l}\text { of } \\
\text { in }\end{array}$ & $\begin{array}{l}\text { S.rolfsii } \\
\text { following }\end{array}$ & $\begin{array}{c}\text { at } \\
\text { concentratio } \\
\mathrm{n}\end{array}$ \\
\hline & & & $24 \mathrm{hr}$ & $\%$ of I & $48 \mathrm{hr}$ & $\%$ of I & $72 \mathrm{hr}$ & $\%$ of I \\
\hline \multirow{5}{*}{1} & \multirow{5}{*}{$\begin{array}{c}\text { Brassica } \\
\text { compestris } \\
\text { Linn. }\end{array}$} & $10 \%$ & 21 & 0 & 51 & 8.928 & 78.66 & 8.534 \\
\hline & & $25 \%$ & 21 & 0 & 47.33 & 15.48 & 78 & 9.302 \\
\hline & & $50 \%$ & 19.33 & 6.380 & 47 & 16.07 & 76.33 & 11.24 \\
\hline & & $75 \%$ & 20 & 4.761 & 47.33 & 15.48 & 76.66 & 10.86 \\
\hline & & Control & 21 & & 56 & & 86 & \\
\hline \multirow{5}{*}{2} & \multirow{5}{*}{$\begin{array}{l}\text { Annona } \\
\text { squamosa } \\
\text { Linn. }\end{array}$} & $10 \%$ & 19.66 & 10.63 & 47.66 & 13.34 & 73.00 & 8.750 \\
\hline & & $25 \%$ & 21.33 & 3.045 & 47.33 & 13.94 & 75.66 & 5.425 \\
\hline & & $50 \%$ & 18.66 & 15.18 & 49.66 & 9.709 & 77.33 & 3.337 \\
\hline & & $75 \%$ & 18.66 & 15.18 & 42.66 & 22.43 & 70.33 & 12.08 \\
\hline & & Control & & & & & & \\
\hline \multirow{5}{*}{3} & \multirow{5}{*}{$\begin{array}{l}\text { Ocimum } \\
\text { sanctum } \\
\text { Linn. }\end{array}$} & $10 \%$ & 20 & 20 & 48 & 12.72 & 73 & 3.947 \\
\hline & & $25 \%$ & 18.66 & 25.36 & 46.83 & 14.85 & 74.33 & 2.197 \\
\hline & & $50 \%$ & 17 & 32 & 47 & 14.54 & 73.33 & 3.513 \\
\hline & & $75 \%$ & 17.33 & 30.68 & 44 & 20 & 68.33 & 10.09 \\
\hline & & Control & & & & & & \\
\hline
\end{tabular}

* Values are average of triplicate.

* Values measured after deducting or reducing 4mm mycelium disk. 
* (I) is denoted for inhibition.

* Note 1- 10\%, 25\%, 50\%, 75\% and Control (100\%) are aqueous medium leaves extract.

Graph 1, 2:- Inhibition of Sclerotium rolfsii in Annona squamosa Linn and Brassica compestris Linn. leaves extract as following.

Graph 1

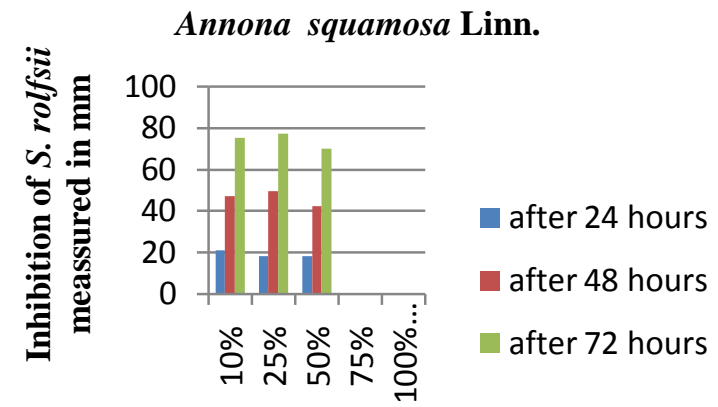

Concentration in Percentage
Graph 2

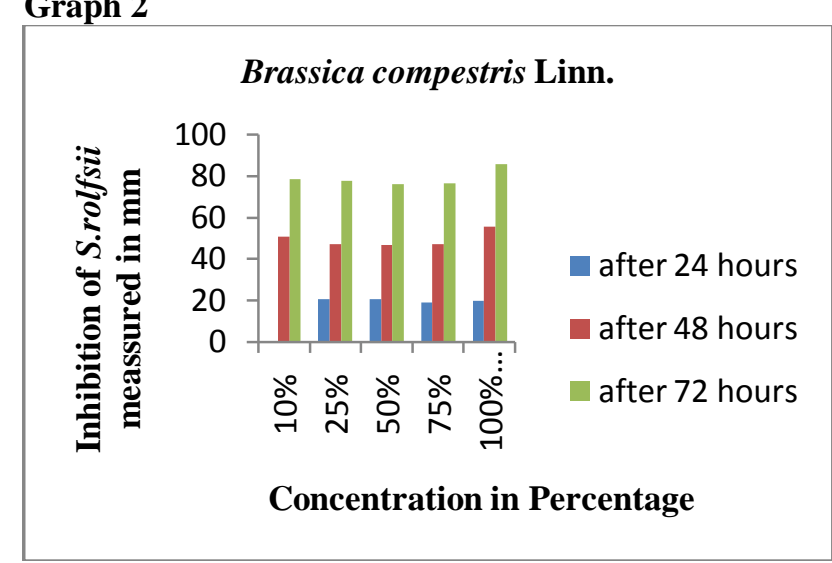

Graph 3:- Inhibition of Sclerotium rolfsii in Ocimum sanctum Linn leaves extract.

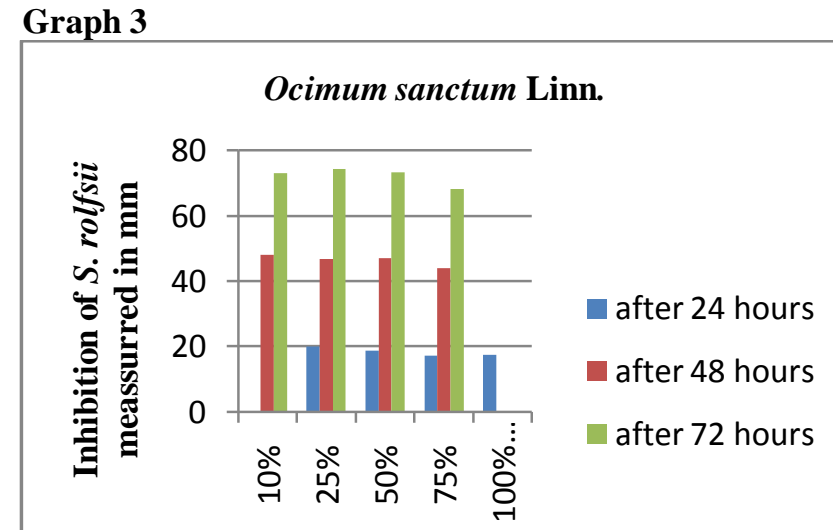

Concentration in Percentage

Graph 4, 5:- The percentage of inhibition of Sclerotium rolfsii in Anonna squamosa Linn. and Brassica compestris.

Graph 4

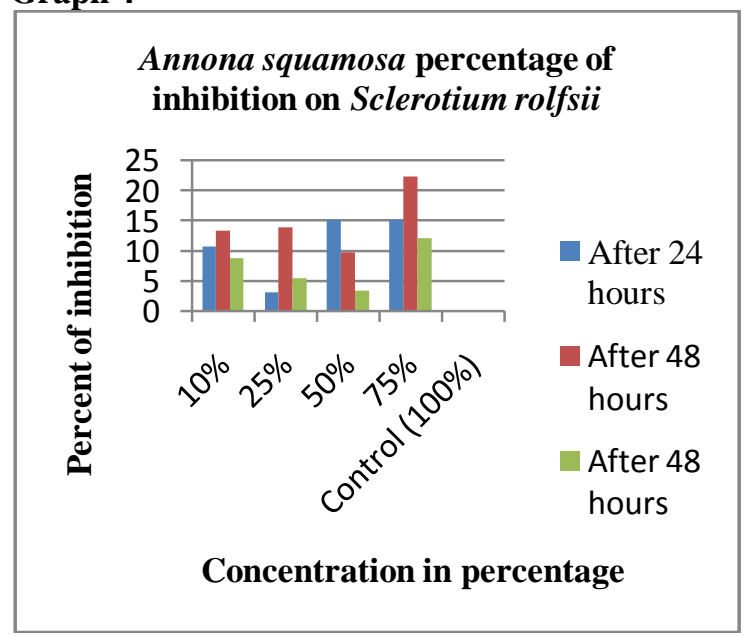

Graph 5




Graph 6:- The percentage of inhibition of Sclerotium rolfsii in Ocimum sanctum.

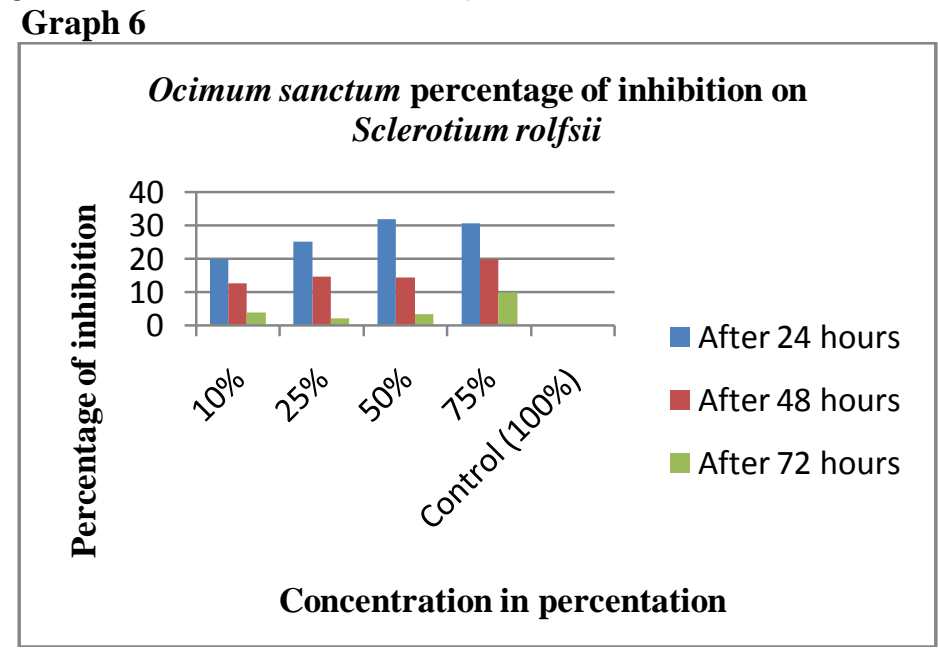

Figure 1: Plant extracts [4] Annona squamosa, [5] Brassica compestris and [6] Ocimum sanctum in following concentration after 72 hours of incubation period.

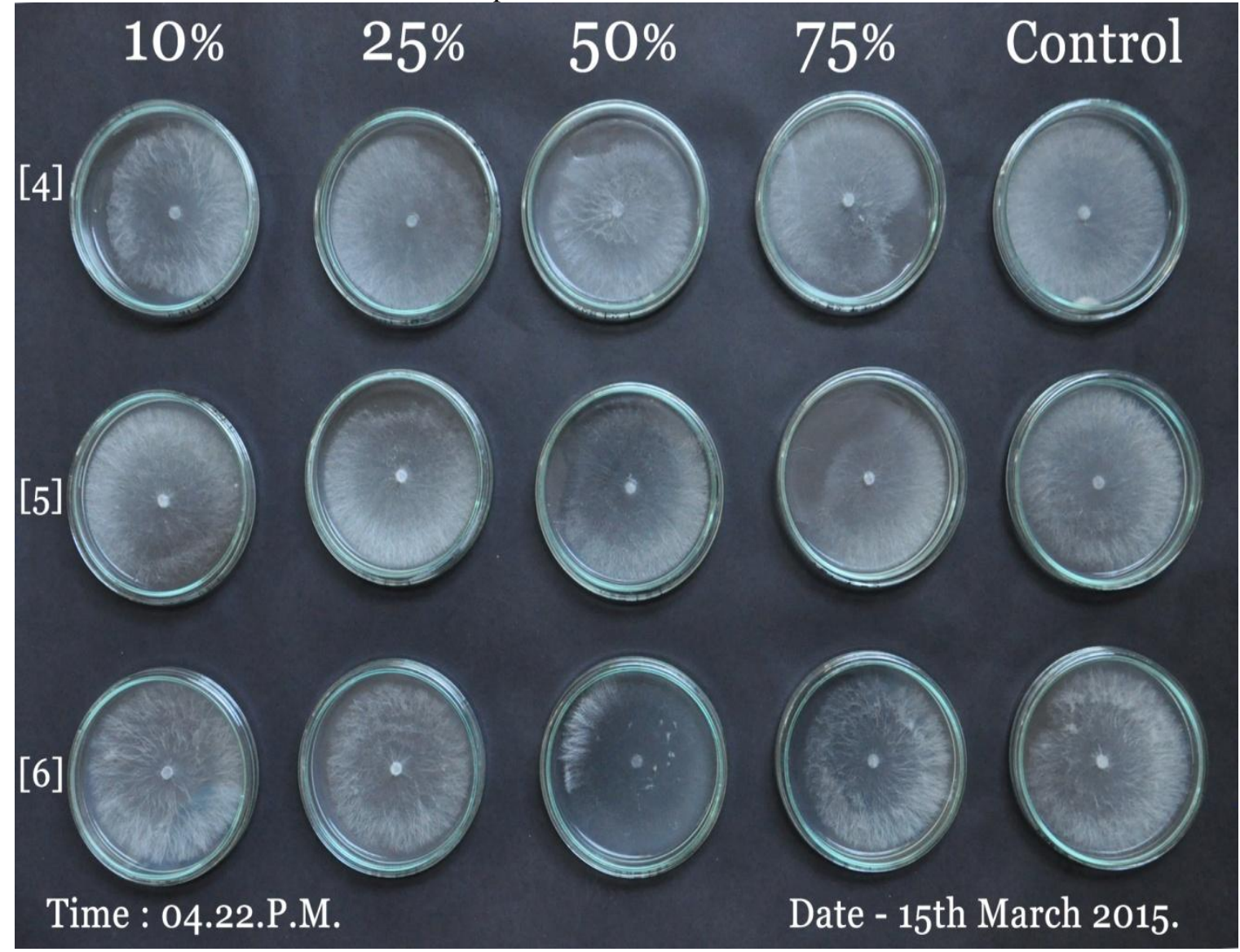

\section{Conclusion:-}

The management of fungal diseases in vegetables with chemicals, under field condition is cost prohibitive, hazardous and cause serious environmental pollution. So efforts are being made these days to shift from the conventional use of chemicals to the use of eco-friendly botanicals for the management. Organic amendments are 
not safe to use but also have the capacity to improve soil structure and fertility. Thus, control strategies are now directed towards the use of natural products.

The conclusion of study is Annona squamosa Linn, Brassica campestris Linn. (Sarson) and Ocimum sanctum Linn aqueous extract inhibited the Sclerotium rolfsii under in vitro condition.

\section{Acknowledgement:-}

Author's grateful to Dr. Sumia Fatima my Guide, Associate Professor and Head of the department of Botany for use full instruction direction. The author's are also express gratitude to principal of Dr. Rafiq Zakaria College Campus-2 and Dr. Babasaheb Ambedkar Marathada University, Aurangabad (M.S.) comfort and provided that necessary amenities for this research work.

\section{References:-}

1. Al-Mughrabi, K.I., (2003). Antimicrobial activity of extracts from leaves, stem and flowers of Euphorbia macroclada against plant pathogenic fungi. Phytopathol. Mediterranean, 42: 245-250.

2. Awuah, R.T, (1989). Fungi toxicity effect of extracts from some West African Plants. Annal.Appl. Biol., 115: 445-453.

3. Darvin G. (2013). Effect of plant extracts on radial growth of Sclerotium rolfsii Sacc. causing stem rot of Ground nut. International Journal of Applied Biology and Pharmaceutical Technology. Vol: 4, Issue: 4, pp-6973.

4. Dhingra, O.D. and Sinclair, J.B. (1985). "Basic Plant Pathology Methods". CBS Publishers. 7. 232. 1985.

5. Hale C.N., Mathers D.J., (1977). Toxicity of white clover seed diffusate and its effects on the survival of Rhizobium trifolii. New Zealand Agric Res., 20: 69-73.

6. Hoffman, B. R., A. Delas, K. Blanko, N, Wiederhold, R. E. Lewis and L. Williams, (2004). Screening of antibacterial and antifungal activities of ten medicinal plants from Ghana.Pharm.Biol. 42: 13-17.

7. Islam, M. T., M. R. Islam, F. M. Aminuzzaman and S. Yesmin, (2007). Management of damping off vegetables seedlings through some selected soil amendments and chemicals. Journal of Agricultural Sciences and Technology, 8(2): 27-31.

8. Ismail, M., Z. Iqbal, B. Ahmad, S. Zakir and U. Naiz, (2003). Biological and pharmacological properties of two indigenous medicinal plants, Rheum emodi and Paeonia emodi. Pak. J. Biol. Sci., 6: 984-986.

9. Jalal, A. O and Ghaffar, A. (1992). Antifungal properties of Ocimum sanctum L. National Symposium on the Status of Plant Pathology in Pakistan. Univ. of Karachi., pp. 283-287.

10. Kalo F. and Taniguchi, T. (1987). Properties of a virus inhibitor from spinach leaves and mode of action. Ann. of Phytopath. Sec. Japan, 53:159-167.

11. Kandasamy D, Keseran R. Ramasamy K. Prasad N. N., (1974). Occurrence of microbial in the exudates of certain leguminous seeds. J.Microbial. 14-25-30.

12. Kondratyak, T.P. and J.M. Pezzuto, (2004). Natural product polyphenols of relevance to human health. Pharm. Biol., 42: 46-63.

13. Kumar, A. Shukla, R., Sing, P., Prasad, C. S., and Dubey, N. K. (2008).Assessment of thymus vulgaris L.essential oil as a safe botanical preservative against post harvest fungal infestation of food commodities. Food Science. Emerg. 4: 575-580.

14. Okigbo, R. N. and Ogbonnaya, O. U. (2006). Antifungal effects of tropical plants extracts O.gratissimum and A.melegueta on post harvest yam Dioscore sp. rot. Aftr. J. Biotechnol., 5: 727-731.

15. Mothana, R.A.A. and U. Lindequist, (2005). Antimicrobial activity of some medicinal plants of the island Soqotra. J. Ethnopharmacol., 96: 177-181.

16. Parajuli, D.P., A.R.Gyawali and B.M.Shrestha. (1998). A Manual of important Non-timber Forest Product in Nepal. Training and manpower development in C.F.M.Pokhara Nepal.

17. Patil, J and J.Katan. (1997). Effect of cultivation practices and cropping systems on the soil borne.

18. Rahber-Bhatti M.H, (1986).Control of Phakospora grewia with Plant diffusates. Pak.J.Bot. 18: 329-333.

19. Sehajpal, Anil, Saroj Arora and Parminder Kaur. (2009).Evaluation of plant extract against Rhizoctoina solani causing sheath blight of rice. The Journal of Plant Protection Sciences, 1(1): 25-30.

20. Zaidi, M.A. and S.A. Crow, (2005). Biologically active traditional medicinal herbs from Balochistan, Pakistan. J. Ethnopharmacol., 96: 331-334. 